\title{
Keanekaragaman Fitoplankton Sebagai Indikator Kualitas Air Danau Sipin Di Kota Jambi
}

\author{
Guntar M. Saragih dan Winda Erizka*
}

\author{
Program Studi Teknik Lingkungan, Fakultas Teknik, Universitas Batanghari \\ *e-mail : werizka19@gmail.com
}

\begin{abstract}
ABSTRAK
Fitoplankton mempunyai peranan yang penting dalam suatu perairan, selain sebagai dasar rantai pakan (primery producer) juga merupakan salah satu tingkat parameter kualitas suatu perairan. Penelitian ini dilaksanakan sesaat satu hari pada bulan November 2017 di Danau Sipin Kota Jambi pada 3 (tiga) titik lokasi dengan metode survey dan random sampling. Kelimpahan yang diperoleh dengan rata-rata total $2464 \mathrm{sel} / \mathrm{L}$. Kisaran nilai indeks biologi yang ditemukan adalah indeks keanekaragaman $\left(\mathrm{H}^{\prime}\right)=1,885-2,204$. Parameter fisika-kimia perairan yaitu suhu 298C, kekeruhan 1,30-4,02 NTU, pH 6,39-6,71, BOD 2,42-2,82 mg/L, DO 4,41-5,10 mg/L, nitrat $0,112-0,229 \mathrm{mg} / \mathrm{L}$, dan pospat $0,018-0,036 \mathrm{mg} / \mathrm{L}$. Hasil analisis regresi linier dan korelasi berganda ditemukan bahwa terdapat hubungan namun sangat lemah antara parameter fisik-kimia perairan dengan kelimpahan fitoplankton $(\mathrm{r} 2=0,003)$ dan persamaan regresi $\mathrm{Y}=2360,99-0,00005$ suhu $+0,008$ kekeruhan $+0,006 \mathrm{pH}+0,027 \mathrm{BOD}+0,036 \mathrm{DO}+0,226$ nitrat +0 pospat serta memilliki nilai indeks saprobik $(-1,625)$ yang artinya terjadi pencemaran organik sangat berat atau tingkat pencemaran kelas 4 (empat) dan pesebaran kemerataan $(\mathrm{E})=0,665-0,835$ yang artinya merata.
\end{abstract}

Kata Kunci : Fitoplankton; Kualitas Air; Perairan Danau Sipin Kota Jambi; Tingkat Hubungan (Korelasi).

\section{ABSTRACT}

Phytoplankton have an important role in a waters, as well as the base of the feed chain (primery producer) is also one of the parameters of the quality of a waters. This research was conducted for one day in November 2017 at Sipin Lake Jambi City on 3 (three) location points with survey and random sampling method. Abundance obtained with an average total of 2464 cells / L. The range of biological index values found is the index of diversity $\left(H^{\prime}\right)=1,885-2,204$. Physics-chemical parameters of instantaneous water are temperature 298C, turbidity 1,30-4,02 NTU, pH 6,39-6,71, BOD 2,42-2,82 mg / L, DO 4,41-5, $10 \mathrm{mg} / \mathrm{L}$, nitrate 0,112$0,229 \mathrm{mg} / \mathrm{L}$, and pospat 0,018-0,036 $\mathrm{mg} / \mathrm{L}$. The result of linear regression analysis and multiple correlation found that there is a very weak but correlation between physicochemical parameter of aquatic with phytoplankton abundance $(r 2=0,003)$ with regression equation $Y=2360,99-0,00005$ temperature $+0,008$ turbidity $+0,006 \mathrm{pH}+0,027 \mathrm{BOD}+0,036 \mathrm{DO}+0,226$ nitrate +0 pospat and have index value of saprobik $(-1,625)$ which mean very heavy organic contamination or level of pollution class 4 (four) and fairness distribution $(E)=0,665-0,835$ which means evenly.

Keywords: Phytoplankton; Water Quality; Lake Sipin Water Jambi City; Relationship Level (Correlation).

\section{Pendahuluan}

Kualitas air suatu perairan erat kaitannya dengan potensi perairan terutama ditinjau dari indikator biologi yang dapat dipantau secara kontiniu dan merupakan indicator yang mudah untuk memantau terjadinya pencemaran. Keberadaan organisme perairan merupakan indikator pencemaran air selain indikator fisika dan kimia. Plankton dapat dijadikan sebagai indikator pencemaran karena bersifat toleran terhadap bahan pencemar. Sehingga plankton menjadi informasi mengenai kondisi suatu perairan. Plankton terdiri atas fitoplankton yang merupakan produsen utama zat-zat organik dan zooplankton yang tidak dapat memproduksi zat-zat organik (Fachrul, 2006)

Fitoplankton mempunyai peranan yang sangat penting di perairan, yaitu sebagai dasar dari rantai pakan, dan salah satu parameter tingkat pencemaran suatu perairan. Terdapat jenis-jenis fitoplankton yang dapat digunakan sebagai indikator untuk mengetahui pencemaran perairan. Penelitian tentang kandungan fitoplankton di berbagai perairan baik antar wilayah perairan maupun antar perairan tertentu menunjukan adanya keragaman jumlah dan jenisnya, meskipun lokasi relatif berdekatan dan berasal dari massa air yang sama. Perbedaan tersebut dibedakan oleh faktor suhu, kecerahan, kedalaman, zat hara, $\mathrm{pH}, \mathrm{BOD}$, dan pecampuran massa air menyebabkan perbedaan tersebut (Davis, 1995)

Danau Sipin berada di tiga kelurahan yaitu Kelurahan Legok, Kelurahan Buluran dan Kelurahan Sungai Putri Kecamatan Telanai Pura Kota Jambi. Pada koordinat 01820'16,35" LS. Danau ini memiliki Luas \pm $227 \mathrm{Ha}$ dan Volume $\pm 8.347 .000 \mathrm{~m} 3$, memiliki kedalaman normal 3,50-5,00 $\mathrm{m}$ yang membujur sepanjang desa dengan dasar bentuk seperti cekungan. Sumber air masuk berasal dari Sungai Buluran I, Sungai Buluran II, dan Sungai Putri dan bermuara ke Desa Pulau Pandan menuju Sungai Batanghari (Status Lingkungan Hidup Daerah Kota Jambi, 2016). Saat ini Danau Sipin sedang mengalami semakin berkurangnya kapasitas penampungan air danau. Aktivitas manusia seperti usaha budidaya ikan dan pencemaran buangan 
limbah rumah tangga dan industri mengakibatkan turunnya kualitas fisik dan kimia air, berkurangnya produksi perikanan karena adanya pencemaran, pendangkalan dan eksploitasi penangkapan yang berlebihan.

Penurunan kualitas air ini akan mempengaruhi biota yang ada di perairan tersebut diantaranya adalah fitoplankton dan menurunkan tingkat kualitas di perairan tersebut. Salah satu parameter yang dapat digunakan untuk menilai besarnya penurunan kualitas suatu perairan adalah parameter biologi dengan menggunakan indeks saprobitas dan indeks biologi seperti keanekaragaman dan kemerataan fitoplankton (Fachrul, 2006). Tujuan dilakukannya penelitian ini adalah untuk mengetahui hubungan parameter fisikkimia kualitas perairan sebagai faktor yang mempengaruhi kehidupan fitoplankton di perairan Danau Sipin berdasarkan PP No.82 Tahun 2001, untuk mengetahui kualitas air Danau Sipin berdasarkan indeks saprobitas fitoplankton dan untuk mengetahui persebaran kemerataan fitoplankton ditinjau dari arah arus air danau.

\section{Metode Penelitian}

Penelitian ini dilakukan pada bulan November hingga Desember 2017 dengan pengambilan sampel pada tanggal 03 November di Danau Sipin Kota Jambi. Analisis kualitas air dilakukan di UPTB Laboraturium Dinas Lingkungan Hidup Provinsi Jambi dan identifikasi fitoplankton dilakukan di Laboraturium PT. SKY PACIFIC INDONESIA, Bogor.

Bahan yang digunakan dalam penelitian ini adalah air Danau Sipin, beberapa tetes lugol dan rosebengal. Alat yang digunakan dalam penelitian ini adalah Plankton Net, Mikroskop Cahaya, Ember Plastik, Water Quality Checker, Termometer Air Raksa, Sedgwick Rafter, Pipet tetes, Counter, pH Universal, Botol Sampel ukuran $30 \mathrm{ml}, 100 \mathrm{ml}, 500 \mathrm{ml}$ dan $1000 \mathrm{ml}$, DO meter, GPS, Alat tulis, Kamera, Kertas label.

Penelitian dilakukan dengan metode survey lapangan. Tahapan pada penelitian ini meliputi pengumpulan data, penentuan titik sampling, pengambilan sampel fitoplankton dan kualitas air serta analisis data.

\section{Penentuan Titik Sampling}

Pengambilan sampel dilakukan secara acak (random sampling). Penentuan titik sampling untuk penelitian ini menggunakan alat bantu GPS dan ditentukan tiga titik sampling yaitu hulu, tengah dan hilir. Peta titik sampling dapat dilihat pada

Pengambilan sampling air dilakukan pada bagian permukaan danau karena kedalaman perairan yang relatif dangkal, pengambilan sampel airnya dilakukan dengan menggunakan ember plastik yang Gambar 1 . diambil secara vertikal sebanyak 3 kali pengulangan, lalu dipekatkan ke dalam plankton net. Sampel air yang telah diambil sebanyak 50 liter kemudian disaring dan dimasukkan ke dalam botol sampel (PE) berukuran 500 $\mathrm{ml}$ yang telah terisi lugol hingga warna air menjadi coklat kemerahan, lalu diberi label pada masing-masing titik sampling di botol PE dan kemudian diawetkan. Setelah semua pengambilan sampel selesai, dikirim ke Laboraturium PT. SKY PACIFIC INDONESIA, Bogor untuk dilakukannya identifikasi fitoplankton pada masing-masing sampel tersebut.

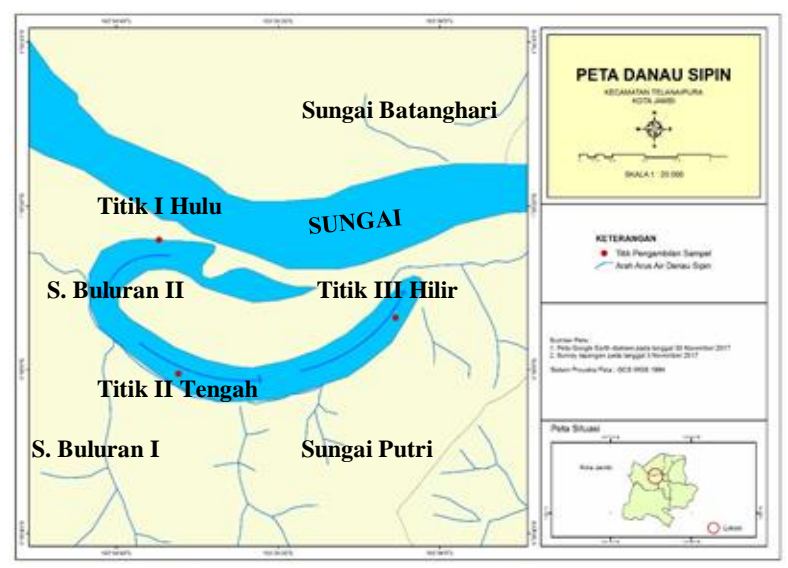

Gambar 1. Peta Lokasi Penelitian

\section{Identifikasi Fitoplankton}

Sampel air yang telah didapat diamati dengan mikroskop cahaya di Laboraturium PT. SKY PACIFIC INDONESIA , Bogor. Air dalam botol sampel digoyang-goyangkan untuk menjaga homogenitas fitoplankton di dalamnya. Sampel air dituangkan ke dalam gelas ukur. Gelas ukur yang berisi sample air dituangkan kembali ke dalam Sedgwick-Rafter cell untuk di cacah dengan menggunakan pipet tetes. Pengamatan dilakukan secara mikroskopis menggunakan mikroskop cahaya dengan pembesaran $10 \mathrm{x}, 40 \mathrm{x}$ dan $100 \mathrm{x}$ dengan bantuan rosebengal agar mudah diamati dan diidentifikasi fitoplanktonnya. Penghitungan dilakukan dengan menggunakan counter.

\section{Analisis Data}

Analisis data yang digunakan ialah secara deskriptif dan ekologi kuantitatif melalui Indeks Saprobitas penetuan tingkat pencemaran dan Perhitungan sruktur komunitas fitoplankton baik kelimpahan, keanekaragaman dan kemerataan fitoplankton. Serta melihat tingkat hubungan dari kualitas air dengan kelimpahan fitoplankton yang dianalisis secara statistik korelasi ganda dengan menggunakan persamaan :

\section{Nilai Koefisien Saprobik Fitoplankton}

Indeks saprobitas merupakan perhitungan untuk menentukan tingkat kualitas perairan. Sitem saprobik ini hanya untuk melihat kelompok organisme yang dominan saja dan banyak digunakan untuk menentukan tingkat pencemaran dengan persamaan Dresscher dan van Der mark (Koesoebiono, 1987) yang dapat dilihat berikut ini :

$$
X=\frac{C+3 D-B-3 A}{A+B+C+D}
$$

Keterangan :

$\mathrm{X}=$ Koefisien Saprobik (-3 sampai 3)

$\mathrm{A}=$ Jumlah organisme divisi Cyanophyta 
$\mathrm{B}=$ Jumlah organisme divisi Chloropthya,

Bacillariophyta

$\mathrm{C}=$ Jumlah organisme divisi Dinophyta

$\mathrm{D}=$ Jumlah organisme divisi Chrysophyta

Tabel 1 Hubungan Antara koefisien Saprobitas Perairan (X)dengan Tingkat Pencemaran Perairan.

\begin{tabular}{|c|c|c|c|}
\hline $\begin{array}{c}\text { Bahan } \\
\text { Pencemar }\end{array}$ & $\begin{array}{c}\text { Tingkat } \\
\text { Pencemar }\end{array}$ & Fase Saprobik & $\begin{array}{l}\text { Koefisien } \\
\text { Saprobik }\end{array}$ \\
\hline \multirow{2}{*}{$\begin{array}{l}\text { Bahan } \\
\text { Organik }\end{array}$} & $\begin{array}{l}\text { Sangat } \\
\text { Berat }\end{array}$ & $\begin{array}{c}\text { Polisaprobik } \\
\text { Poli / } \alpha \text { - Mesosaprobik }\end{array}$ & $\begin{array}{c}(-3)-(-2) \\
(-2)-(-1,5)\end{array}$ \\
\hline & $\begin{array}{l}\text { Cukup } \\
\text { Berat }\end{array}$ & $\begin{array}{c}\alpha-\text { Meso/Polisaprobik } \\
\alpha-\text { Mesosaprobik }\end{array}$ & $\begin{array}{l}(-1,5)-(-1) \\
(-1)-(-0,5)\end{array}$ \\
\hline \multirow{2}{*}{$\begin{array}{l}\text { Bahan } \\
\text { Organik } \\
\text { Dan } \\
\text { Anorganik }\end{array}$} & Sedang & $\begin{array}{l}\alpha / \beta \text { - Mesosaprobik } \\
\beta / \alpha-\text { Mesosaprobik }\end{array}$ & $\begin{array}{c}(-0,5)-(0) \\
(0)-(0,5)\end{array}$ \\
\hline & Ringan & $\begin{array}{c}\beta \text { - Mesosaprobik } \\
\beta- \\
\text { Meso/Oligosaprobik }\end{array}$ & $\begin{array}{l}(0,5)-(1,0) \\
(1,0)-(1,5)\end{array}$ \\
\hline $\begin{array}{c}\text { Bahan } \\
\text { Organik } \\
\text { Dan } \\
\text { Anorganik }\end{array}$ & $\begin{array}{l}\text { Sangat } \\
\text { Ringan }\end{array}$ & $\begin{array}{c}\text { Oligo/ } \beta \text {-Mesosaprobik } \\
\text { Oligosaprobik }\end{array}$ & $\begin{array}{l}(1,5)-(2) \\
(2)-(3,0)\end{array}$ \\
\hline
\end{tabular}

Sumber : Suwando et al, 2004

\section{Indeks Keanekaragaman (H')}

Indeks Shannon-Wiener menjelaskan bahwa, untuk menghitung indeks keanekaragaman menggunakan rumus sebagai berikut:

Keterangan :

$$
\mathbf{H}^{\prime}=-\sum(\mathbf{P i} \operatorname{Iog} \mathbf{P i}), \operatorname{dimana} \mathbf{P i}=\mathbf{n i} / \mathbf{N}
$$

H' = Indeks Keanekaragaman Shannon-Wiener

$\mathrm{Pi}=$ Kelimpahan relative

ni $=$ Jumlah individu semua jenis ke-i

$\mathrm{N}=$ Jumlah semua total jenis dalam komunitas

3. Indeks Kemerataan ( $\mathrm{E}$ )

Indeks keseragaman/kemerataan dihitung dengan menggunakan formulasi sebagai berikut:

$$
\mathbf{E}=\mathbf{H}^{\prime} / \mathbf{H} \max
$$

Keterangan :

$\mathrm{E} \quad=$ Indeks keseragaman

H' = Indeks keanekaragaman

$\mathrm{H}$ max $=$ Keragaman maksimum

\section{Indeks Kelimpahan (Ind/L)}

Kelimpahan plankton secara kuantitatif berdasarkan kelimpahan yang dinyatakan dalam individu/ L yang dihitung dengan rumus Sachlan (1982):

$$
\mathbf{N}=\mathbf{V} / \mathbf{V d} \times \mathbf{t} / \mathbf{V s} \times \mathbf{F}
$$

Keterangan:

$\mathrm{N}=$ Kelimpahan Plankton $(\mathrm{ml})$

$\mathrm{V}=$ Volume air sampel $(\mathrm{ml})$

$\mathrm{Vd}=$ Volume air sample yang disaring $(\mathrm{ml})$

$\mathrm{t} \quad=$ Volume air dalam obyek gelas $(\mathrm{ml})$

Vs $=$ Volume air pada Sedgwick-Rafter

$\mathrm{F}$ = Jumlah plankton yang tercacah

\section{Analisis Korelasi}

Analisis korelasi digunakan untuk melihat hubungan antara beberapa parameter fisika-kimia dengan kelimpahan fitoplankton. Menurut Sugiyono (2005), tingkat hubungan nilai indeks Korelasi dinyatakan sebagaimana pada tabel berikut : di Kota Jambi (Saragih, G.M dan Erizka, W)

Tabel 2 Tingkat Korelasi/Hubungan

\begin{tabular}{cc}
\hline Interval Koefisien & Tingkat Hubungan \\
\hline $0,00-0,199$ & Sangat Lemah \\
\hline $0,20-0,399$ & Lemah \\
\hline $0,40-0,599$ & Sedang \\
\hline $0,60-0,799$ & Kuat \\
\hline $0,80-1,00$ & Sangat Kuat \\
\hline \multicolumn{2}{c}{ Sumber : Sugiyono, 2005}
\end{tabular}

\section{Hasil Dan Pembahasan}

\section{Hasil Uji Kualitas Air Parameter Fisika-Kimia}

Parameter fisika yang di ukur selama penelitian adalah pengukuran suhu dan kekeruhan. Dimana pengukuran suhu perairan ini dilakukan langsung di tempat (insitu) pada tiap titik sampling perairan danau sipin dan pengukuran pada kekeruhan dilakukan di UPTB Laboraturium Dinas Lingkungan Hidup Provinsi Jambi. Hasil uji laboraturium dari penelitian dapat

\begin{tabular}{|c|c|c|c|c|}
\hline No & Parameter & $\begin{array}{l}\text { Titik I } \\
\text { (Hulu) }\end{array}$ & $\begin{array}{c}\text { Titik II } \\
\text { (Tengah) }\end{array}$ & $\begin{array}{c}\text { Titik III } \\
\text { (Hilir) }\end{array}$ \\
\hline 1 & Suhu ${ }^{\circ} \mathrm{C}$ & 29 & 29 & 29 \\
\hline 2 & $\begin{array}{l}\text { Kekeruhan } \\
\text { (NTU) }\end{array}$ & 4.02 & 1.30 & 3.21 \\
\hline
\end{tabular}
dilihat pada Tabel 3 sebagai berikut :

Tabel 3 Faktor fisik yang mempengaruhi perairan

Parameter kimia yang diukur secara langsung (insitu) adalah pengukuran $\mathrm{pH}$ menggunakan $\mathrm{pH}$ meter yang dilakukan pada setiap titik sampling di perairan dan untuk pengukuran parameter kimia lainnya seperti BOD, DO Nitrat dan Fosfat dilakukan di UPTB Laboraturium Dinas Lingkungan Hidup Provinsi Jambi. Hasil uji laboraturium dari penelitian dapat dilihat pada Tabel 4 sebagai berikut :

Tabel 4 Faktor kimiawi yang mempengaruhi perairan

\begin{tabular}{clcccc}
\hline No & Parameter & $\begin{array}{c}\text { Titik I } \\
\text { (Hulu) }\end{array}$ & $\begin{array}{c}\text { Titik II } \\
\text { (Tengah) }\end{array}$ & $\begin{array}{c}\text { Titik } \\
\text { III } \\
\text { (Hilir) }\end{array}$ & $\begin{array}{c}\text { Baku } \\
\text { Mutu } \\
\text { (mg/L) }\end{array}$ \\
\hline 1 & DO (mg/L) & 5.10 & 4.65 & 4.41 & $>4$ \\
2 & BOD (mg/L) & 2.82 & 2.42 & 2.82 & 3 \\
3 & $\begin{array}{l}\text { Pospat } \\
\text { (mg/L) }\end{array}$ & 0.024 & 0.036 & 0.018 & 0,2 \\
4 & $\begin{array}{l}\text { Nitrat } \\
\text { (mg/L) }\end{array}$ & 0.229 & 0.189 & 0.112 & 10 \\
5 & pH & 6.71 & 6.42 & 6.39 & $6-9$ \\
\hline & \multicolumn{5}{c}{ Sumber $:$ Data Primer, 2017 }
\end{tabular}

Suhu

Berdasarkan hasil pengukuran terhadap suhu perairan di Danau Sipin diperoleh suhu air pada semua titik adalah sama yaitu $29^{\circ} \mathrm{C}$ dengan kisaran suhu yang optimum bagi pertumbuhan plankton, baik itu fitoplankton maupun zooplankton di perairan adalah 20$30^{\circ} \mathrm{C}$ (Effendi, 2003). Berarti dapat dikatakan bahwa secara umum suhu perairan di Danau Sipin dalam kategori baik bagi kehidupan fitoplankton. 


\section{Kekeruhan}

Pada titik sampling 1 merupakan kekeruhan tertinggi yaitu 4,02 NTU, dan pada titik sampling 3 memiliki nilai kekeruhan 3,21 NTU dan pada titik sampling 2 merupakan nilai kekeruhan terendah 1,30 NTU. Pada titik sampling 1 nilai kekeruhannya paling tinggi yaitu 4,02 NTU. Pada lokasi ini debit air yang masuk ke perairan lebih banyak karna memiliki dua aliran sungai yang masuk sehingga terjadi adukan massa air dan bahan tersuspensi yang tinggi sehingga menyebabkan kekeruhan yang mengurangi kedalaman penetrasi cahaya matahari ke dalam air dan juga disebabkan karena pada pengambilan sampel dilakukan di pinggirpinggir danau sehingga kedalaman air juga dangkal dan terdapat bebatuan serta batang pohon yang dibuang ke pinggiran danau. Kekeruhan yang tinggi dapat menyebabkan terganggunya sistem daya lihat organisme aquatik dan menghambat penetrasi cahaya masuk ke dalam air. Menurut Sukandar (1993), ketidakteraturan kekeruhan disebabkan oleh kontribusi bahan-bahan tiupan angin, aliran air dan kawanan plankton.

\section{DO}

Kehidupan organisme akuatik akan berjalan baik apabila kandungan oksigen terlarutnya minimal $5 \mathrm{mg} / \mathrm{L}$ (Sastrawijaya, 2010). Dari hasil pengukuran nilai DO yang diperoleh di Danau Sipin berkisar antara 4,41 $\mathrm{mg} / \mathrm{L}$ - 5,10 mg/L, dapat dikatakan bahwa kualitas perairan Danau Sipin ini berada pada kondisi normal dan masih layak untuk kehidupan organisme akuatik, karna juga masih diatas batas baku mutu kualitas air menurut PP. No 82 Tahun 2001 (kelas II) yaitu > dari 4 $\mathrm{mg} / \mathrm{L}$.

\section{BOD}

Untuk nilai BOD perairan Danau Sipin memperoleh hasil yang setara karna masih di dalam kisaran angka 2 . Hal ini disebabkan karna pada titik 1, 2 dan 3 memiliki pencemaran organik yang sama-sama berasal dari sisa pelet makanan ikan, mengingat bahwa masyarakat di Danau Sipin masih melakukan budidaya ikan dan juga dapat disebabkan dari sisa-sisa buangan penduduk sekitar danau mengingat bahwa pada danau ini telah penuh dikelilingi oleh permukiman dan dapat pula berasal dari aliran aliran anak sungai yang masuk keperairan. Menurut Effendi (2003) kadar perairan yang dianggap tercemar, yaitu perairan yang mengandung konsentrasi BOD lebih dari $10 \mathrm{mg} / \mathrm{L}$. Dilihat dari hasil penelitian yang telah dilakukan menunjukkan bahwa kualitas perairan Danau Sipin dengan nilai BOD berkisar 2,42-2,82 $\mathrm{mg} / \mathrm{L}$ masih berada dalam kategori yang baik untuk suatu perairan, dimana kadar perairan yang dinyatakan tercemar apabila nilai BOD-nya berada pada kisaran $10 \mathrm{mg} / \mathrm{L}$.

\section{Pospat}

Hasil pengukuran nilai pospat berkisar antara 0.0180,036 . Pada titik 2 merupakan nilai fosfat yang tertinggi 0,036 mg/L hal ini kemungkinan besar disebabkan karna pada titik pengambilan sampling ini berada dekat dengan pertambakan ikan yang bisa saja disebabkan berasal dari feses ikan tersebut serta proses terurainya ikan ikan yang sudah mati, serta terdapat keberadaan rumah sakit yang dekat dengan titik lokasi ini sehingga menghasilkan sisa-sisa makanan berupa buangan dan tidak lepas pula disebabkan oleh pencucian pada alatalat rumah sakit dan rumah warga yang berasal dari aliran anak sungai yang menggunakan sabun pencuci mengandung kadar fosfat, sehingga menyebabkan nilai fosfat di titik ini tinggi. Namun kadar fosfat di Danau Sipin tersebut masih tergolong cukup baik, karna masih dalam batas kehidupan fitoplankton dan standard baku mutu menurut PP. No 82 Tahun 2001 dengan kadar fosfat $0,2 \mathrm{mg} / \mathrm{L}$.

\section{Nitrat}

Pada titik 1 nilai nitrat yang diperoleh lebih besar dari titik 2 dan 3, kemungkinan ini disebabkan karna pembuangan limbah yang berasal dari pemukiman di dua aliran anak sungai yang masuk ke titik 1 dan juga disebabkan karena budidaya ikan yang menghasilkan endapan dari sisa pakan ikan serta juga terjadinya dekomposisi dari limbah organik oleh mikroba yang tidak dimanfaatkan oleh biota akuatik di perairan sehingga dari proses dekomposisi tersebut menghasilkan kadar nitrat. Namun menurut Effendi (2003) jika kadar kadar nitrat lebih besar dari $0,3 \mathrm{mg} / \mathrm{L}$ akan mengakibatkan eutrofikasi (pengayaan) yang selanjutnya menstimulir pertumbuhan algae dan tumbuhan air secara pesat (blooming). Kondisi perairan Danau Sipin jika dilihat dari parameter nitrat yang diperoleh masih tergolong normal untuk kehidupan fitoplankton, karna nilai nya masih di bawah $0,3 \mathrm{mg} / \mathrm{L}$ dan dibawah nilai baku mutu air PP. No 82 Tahun 2001 yang menyatakan bahwa nilai nitrat yang diperbolehkan dalam perairan adalah $<10 \mathrm{mg} / \mathrm{L}$.

\section{pH}

Pada penelitian yang telah dilakukan untuk pengukuran $\mathrm{pH}$ perairan Danau Sipin diperoleh hasil 6,39-6,71. Pada titik sampling ini rata-rata nilainya hampir sama karna masih di dalam angka 6 yang artinya nilai $\mathrm{pH}$ tersebut normal. Kisaran $\mathrm{pH}$ optimum bagi kehidupan fitoplankton adalah pada kisaran $\mathrm{pH}$ 6-8 (Kristanto,2004). Dan berdasarkan standar baku mutu air PP. No 82 Tahun 2001 (kelas II) nilai pH yang optimum adalah 6-9. Dengan demikian $\mathrm{pH}$ pada perairan Danau Sipin dapat dikatakan normal dan memungkinkan untuk pertumbuhan fitoplankton karna nilai $\mathrm{pH}$ pada perairan Danau sipin berada pada angka 6,39-6,71

\section{Kelimpahan Jenis Fitoplankton di Perairan Danau Sipin}

Kelimpahan fitoplankton yang ditemukan di perairan Danau Sipin berdasarkan perhitungan kelimpahan jenis sampel plankton yang diambil secara lengkap dapat dilihat pada Tabel 6 .

Kelimpahan tertinggi diketahui pada jenis spirulina sp (cyanophyta) dengan kelimpahan $653 \mathrm{Sel} / \mathrm{L}$ dan dari total keseluruhan kelompok fitoplankton dengan kelimpahan tertinggi adalah Cyanophyta dengan total kelimpahan 1543 sel/L, sedangkan kelompok Bacillaria dengan total kelimpahan 173 sel/L , kelompok 
Chlorophyta dengan total kelimpahan 371 sel/L, kelompok Coscinodiscophyta dengan total kelimpahan 21 sel/L, kelompok Dinophyta dengan total kelimpahan 7 sel/L, kelompok Euglenophyta dengan total kelimpahan 53 sel/L dan kelompok Zygnematophyta dengan total kelimpahan $296 \mathrm{sel} / \mathrm{L}$. Untuk total semua jenis yaitu 2464 sel/L. Hasil pengukuran disajikan dalam grafik seperti pada Gambar 2.

Tabel 6 Kelimpahan Jenis Fitoplankton

\begin{tabular}{|c|c|c|}
\hline No & Spesies & $\begin{array}{c}\text { Rata- rata } \\
\text { Kelimpahan } \\
\text { Sel/L }\end{array}$ \\
\hline \multicolumn{3}{|c|}{ BACILLARIOPHYCEAE } \\
\hline 1 & Navicula sp. & $21 \mathrm{Sel} / \mathrm{L}$ \\
\hline 2 & Nitzchia sp. & $131 \mathrm{Sel} / \mathrm{L}$ \\
\hline 3 & Pinnularia sp. & $7 \mathrm{Sel} / \mathrm{L}$ \\
\hline 4 & $\begin{array}{l}\text { Tabellaria } s p . \\
\text { CHLOROPHYCEAE }\end{array}$ & $14 \mathrm{Sel} / \mathrm{L}$ \\
\hline 1 & Asterococcus sp. & $14 \mathrm{Sel} / \mathrm{L}$ \\
\hline 2 & Coelastrum sp. & $19 \mathrm{Sel} / \mathrm{L}$ \\
\hline 3 & Pediastrum sp. & $149 \mathrm{Sel} / \mathrm{L}$ \\
\hline 4 & Scenedesmus sp. & $168 \mathrm{Sel} / \mathrm{L}$ \\
\hline 5 & Tetraedron sp. & $21 \mathrm{Sel} / \mathrm{L}$ \\
\hline 1 & $\begin{array}{l}\text { COSCINODISCOPHYCEAE } \\
\text { Coscinodiscus } s p \text {. } \\
\text { CHLOROPHYCEAE }\end{array}$ & $21 \mathrm{Sel} / \mathrm{L}$ \\
\hline 1 & Asterococcus sp. & $14 \mathrm{Sel} / \mathrm{L}$ \\
\hline 2 & Coelastrum sp. & $19 \mathrm{Sel} / \mathrm{L}$ \\
\hline 3 & Pediastrum sp. & $149 \mathrm{Sel} / \mathrm{L}$ \\
\hline 4 & Scenedesmus sp. & $168 \mathrm{Sel} / \mathrm{L}$ \\
\hline 5 & Tetraedron sp. & $21 \mathrm{Sel} / \mathrm{L}$ \\
\hline \multicolumn{3}{|c|}{ COSCINODISCOPHYCEAE } \\
\hline \multicolumn{3}{|c|}{ CYANOPHYCEAE } \\
\hline 2 & Aphanothece sp. & $520 \mathrm{Sel} / \mathrm{L}$ \\
\hline 3 & Chroococcus sp. & $18 \mathrm{Sel} / \mathrm{L}$ \\
\hline 4 & Scenedesmus sp. & $168 \mathrm{Sel} / \mathrm{L}$ \\
\hline 5 & DINOPHYCEAE & $21 \mathrm{Sel} / \mathrm{L}$ \\
\hline 1 & Ceratium sp. & $7 \mathrm{Sel} / \mathrm{L}$ \\
\hline \multicolumn{3}{|c|}{ EUGLENOPHYCEAE } \\
\hline 1 & Euglena sp. & $7 \mathrm{Sel} / \mathrm{L}$ \\
\hline 2 & Phacus sp. & $46 \mathrm{Sel} / \mathrm{L}$ \\
\hline \multicolumn{3}{|c|}{ ZYGNEMATOPHYCEAE } \\
\hline 1 & Zygnema sp. & $296 \mathrm{Sel} / \mathrm{L}$ \\
\hline
\end{tabular}

Kelimpahan dari kelas cyanophyta yang tertinggi pada perairan Danau Sipin diduga karena jenis ini mampu bertahan hidup pada saat cuaca berubah-ubah. Fotosintesis dapat tetap berlangsung oleh jenis cyanophyta walaupun dalam kondisi cuaca mendung maupun terik sekalipun. Hal ini disebabkan karna ganggang hijau-biru ini mampu tumbuh dengan pesat pada suhu tinggi diatas $308 \mathrm{C}$ melebihi suhu optimum pertumbuhan Fitoplankton dan tumbuh optimal dengan rasio N/P < 10. Sehingga pada penelitian di perairan Danau Sipin menghasilkan jenis alga cyanophyceae yang paling tinggi. Kelimpahannya di perairan juga dipengaruhi oleh sifatnya yang menyebar luas umumnya di danau. Ditegaskan oleh pendapat Nontji (2008) bahwa kelimpahan dari jenis cyanophyta umumnya masih tergolong berlimpah ditemukan di danau meskipun dalam kondisi cuaca yang berubah-ubah.

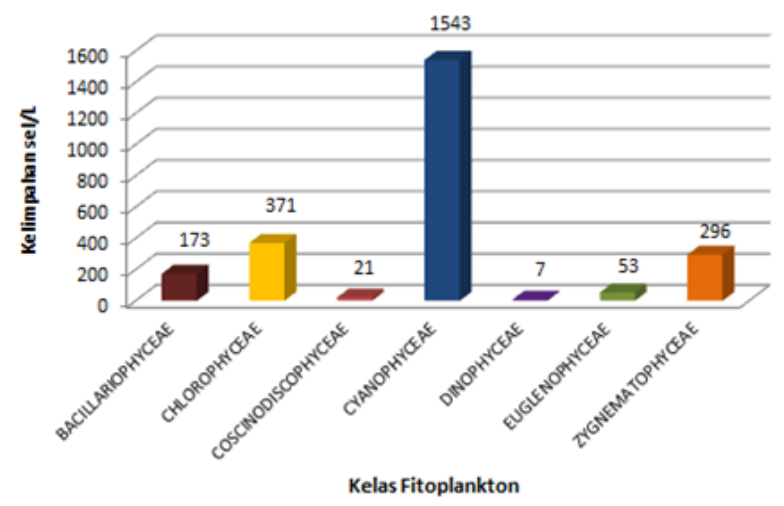

Gambar 2 Kelimpahan Fitoplankton

\section{Hubungan Kualitas Air dengan Kelimpahan Fitoplankton}

Untuk melihat keeratan hubungan antara kualitas air dengan kelimpahan fitoplankton, dalam penelitian ini dilakukan menggunakan analisa statistik korelasi berganda. Analisa statistik ini digunakan untuk mengetahui hubungan antar variabel $x$ dan y. Dalam hal ini variabel $\mathrm{x}$ nya meliputi tujuh parameter berupa $\mathrm{x} 1$ suhu, x2 kekeruhan, x3 pH, x4 BOD, x5 DO, x6 Nitrat dan $\mathrm{x} 7$ dan variabel y nya merupakan total kelimpahan di tiga titik.

Diperoleh nilai koefisien korelasi berganda $\left(\mathrm{r}^{2}\right)$ sebesar 0,003 yang berarti hubungan antara ketujuh parameter kualitas air dan kelimpahan fitoplankton memiliki hubungan yang sangat lemah. Pengujian koefisien korelasi dapat juga dilakukan dengan cara membandingkan nilai koefisien korelasi dengan nilai korelasi tabel atau $r$ tabel (lihat lampiran 2). Sehingga perlu dicari nilai $r$ tabel pada taraf $\alpha=0,05$ dan $n=3$ (jumlah titik sampel) yaitu diperoleh $\mathrm{r}$ tabel sebesar 0,997 . Karena nilai $r$ hitung $(0,003)<\mathrm{r}$ tabel $(0,997)$ maka Ho diterima, artinya tidak terdapat hubungan yang signifikan antara ketujuh parameter kualitas air dengan kelimpahan fitoplankton.

Hal ini dapat terjadi karena nilai-nilai yang diperoleh dari hasil penelitian kualitas air tidak akurat yang disebabkan karna pengambilan sampel air tidak sesuai dengan prosedur yang semestinya untuk pengambilan sampel air pada danau. Sehingga nilai-nilai yang diperoleh dari hasil uji laboraturium memiliki nilai dibawah standard baku mutu dan sangat bertolak belakang dengan hasil uji kualitas air danau sipin yang dilakukan oleh peneliti sebelumnya yang menggolongkan pencemaran danau sipin ini masuk ke kelas 4 tercemar berat yang melebihi baku mutu. Itulah yang menjadi penyebab mengapa hubungan kualitas air danau sipin berpengaruh sangat lemah terhadap kelimpahan fitoplankton di danau sipin.

\section{Indeks Saprobitas}

Hasil analisis indeks saprobitas untuk melihat pencemaran perairan Danau Sipin berdasarkan komunitas fitoplankton dapat dilihat dalam Tabel 7. 
Nilai indeks saprobitas yang diperoleh dari hasil analisis diatas berdasarkan hubungan antara koefisien saprobitas perairan (X) dengan tingkat pencemarana perairan (Suwondo et al, 2004) terkait komunitas fitoplankton terklasifikasikan terjadinya pencemaran bahan organik sangat berat atau poli/ $\alpha$-mesosaprobik dengan nilai saprobik $=-1,625$.

Tabel 7 Indeks Saprobitas Fitoplankton

\begin{tabular}{clc}
\hline Kode & \multicolumn{1}{c}{ Kelas } & Jumlah Jenis \\
\hline A & Cyanophyta & 6 \\
\hline B & Chlorophyta, Bacillariophyta & 9 \\
\hline C & Dinophyta & 1 \\
\hline $\mathrm{D}$ & Chrysophyta & \\
\hline & $\mathrm{X}=1+(3.0)-9-(3.6)$ & \\
& $=\frac{1+0-9-18}{6+9+1+0}$ & $\mathbf{- 1 , 6 2 5}$ (Sangat \\
& $=-1,625$ & Berat)
\end{tabular}

Sumber : Data primer, 2017

Menurut Pantle dan Buck (1995) dalam Basmi (2000) tingkat poli/ $\alpha$-mesosaprobik memiliki ciri-ciri komunitas DO rendah dan BOD tinggi, munculnya fitoplankton yang terdiri dari Cyanophycae, diatom dan blue green algae. Hal ini sesuai dengan hasil penelitian yang didapatkan bahwa jenis algae Cyanophycea dan Bacillariophyceae memiliki jenis spesies yang tinggi.

Pencemaran bahan organik yang terjadi berasal dari aktivitas daratan berupa pemukiman penduduk serta terdapat beberapa aliran dari anak sungai baik pada area hulu, tengah maupun hilir yang telah berubah menjadi area pemukiman dan budidaya ikan. Dari aktivitas tersebut, tentunya akan menghasilkan limbah organik berupa kotoran tinja, sisa makanan (sampah rumah tangga), sisa pakan dari pelet, tumbuh-tumbuhan mati dan hewan yang mati yang terdekomposisi serta bahan organik lain yang mengakibatkan terjadinya penurunan kualitas perairan. Pencemaran bahan organik yang terjadi erat kaitannya dengan kandungan DO rendah yang disebabkan karena jumlah oksigen terlarut digunakan oleh bakteri untuk proses pembusukan dan BOD tinggi. Di perairan Danau Sipin memiliki nilai DO rata-rata 4,72 yang berada dalam ambang batas rendah. Nilai BOD dengan rata-rata $2,68 \mathrm{Mg} / \mathrm{l}$ yang masih berada di bawah baku mutu, namun tergolong tinggi karna hampir mencapai ambang batas.

Berdasarkan nilai rasio N/P bahwa kandungan Nitrat dan Pospat adalah 6,76 yaitu $<10$ yang artinya termasuk dalam kategori pertumbuhan algae cyanophyta tinggi sesuai dengan hasil penelitian dan kriteria tingkat poli/ $\alpha$-mesosaprobik.

\section{Nilai Keanekaragaman Fitoplankton di Perairan Danau Sipin}

Berdasarkan analisis data yang diperoleh di semua titik penelitian, menunjukkan bahwa indeks keanekaragaman fitoplankton di Danau Sipin memiliki hasil nilai di Hulu 1.885, Tengah 2,204, Hilir 2,057.

Nilai keanekaragaman terendah terjadi pada titik sampling 1 (hulu) yaitu 1,885 dikarenakan pada titik sampling ini terdapat banyak pepohonan besar dan rindang sehingga kecerahannya relatif rendah menutupi cahaya matahari masuk kepinggiran perairan tepat dimana sebagai titik sampling dan didukung dengan hasil nilai kekeruhan yang relatif tinggi dari titik sampling 1 dan 2, yaitu 4,02. Sehingga menyebabkan fitoplankton sulit melakukan fotosintetis dan dilihat dari unsur pospat yang mempengaruhi pertumbuhan fitoplankton memiliki hasil nilai yang rendah yaitu 0,024 .

Nilai keanekaragaman tinggi mengacu pada titik sampling 2 dan 3 yaitu 2,204-2,057. Pada titik sampling ini berada di area yang terkena sinar matahari penuh dan tidak ada pepohonan yang menutupi titik pengambilan sampling sehingga masuknya cahaya matahari lebih banyak dan didukung dengan hasil nilai kekeruhan yang rendah dari titik 1 yaitu 1,30 sehingga mempercepat fitoplankton melakukan fotosintesis dan juga memiliki kaadar pospat lebih besar yaitu 0.036 yang membantu pertumbuhan fitoplankton. Oleh karena itu terdapat cukup banyak keanekaragam fitoplankton pada titik sampling ini, sehingga menyebabkan keanekaragaman sedikit lebih tinggi dari titik sampling 1 .

Mengacu kepada klasifikasi indeks keanekaragaman Shannon-Wiener, indeks keanekaragaman fitoplankton di Danau Sipin termasuk kedalam kategori keanekaragaman dan penyebaran jumlah individu setiap jenis fitoplankton sedang yaitu berada diantara $1,0<\mathrm{H}^{\prime}$ 3,0 . Hasil tersebut didapatkan dari analisis nilai indeks keanekaragaman fitoplankton pada masing-masing titik dimana memiliki nilai antara 1,885-2,20.

\section{Pesebaran Kemerataan Fitoplankton Berdasarkan Arah Arus Air Danau Sipin}

Pada penelitian yang telah dilakukan diketahui bahwa arah arus air Danau Sipin dari titik 1 Hulu menuju ke muara yaitu titik 3 Hilir dimana arusnya mengarah kearah timur. Untuk melihat pola pesebaran fitoplankton merata atau tidaknya akan dihitung dengan menggunakan indeks kemerataan. Indeks ini menunjukan pola sebaran biota perairan, yaitu merata atau tidak dilihat dari apabila nilai E mendekati 0, maka kemerataan antara spesies rendah. Apabila nilai E mendekati 1, maka kemerataan antara spesies relatif merata (Fachrul, 2006). Dari hasil perhitungan nilai kemerataan fitoplankton dapat dilihat pada gambar 3.

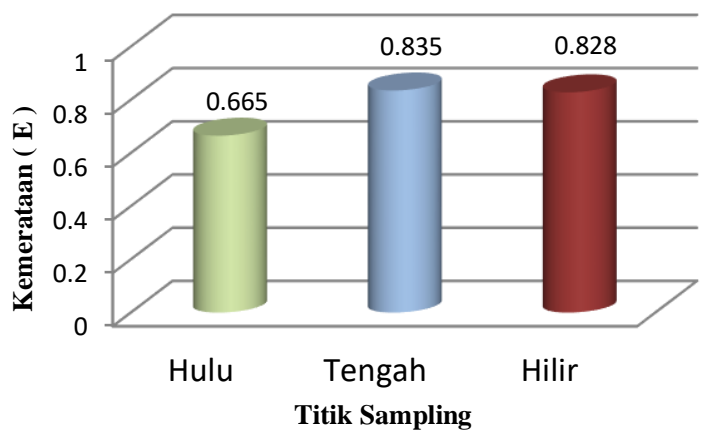

Gambar 3. Pesebaran Kemerataan Fitoplankton (sumber : Data Primer)

Nilai kemerataan diatas menunjukkan bahwa kemerataan populasi pada semua titik sampling seragam dengan nilai yang relatif tinggi atau mendekati 1 
sehingga dapat disimpulkan pesebaran spesies relatif merata dengan arah arus air ke timur.

Tingginya kemerataan pada semua titik sampling karena spesies yang merata, sehingga tidak terjadinya kecenderungan terhadap suatu spesies. Menurut Fachrul (2006), menyatakan bahwa apabila nilai E mendekati 0, maka kemerataan antara spesies rendah. Apabila nilai E mendekati $1(>0,5-1)$, maka kemerataan antara spesies relatif merata dan hal ini juga berdasarkan uji laboraturium parameter kandungan kualitas air pada titik sampel 1, 2 dan 3 yang cenderung memiliki hasil nilai yang tidak berbeda jauh dan berdasarkan PP. No 82 Tahun 2001 hasil dari ketiga titik sample tersebut masih dibawah standard baku mutu. Sehingga dapat disimpulkan bahwa penyebaran fitoplankton di Danau Sipin dilihat dari hasil perhitungan kemerataan fitoplankton dan uji kualitas air di ketiga titik sampel tersebut dinyatakan merata.

\section{Kesimpulan dan Saran}

Berdasarkan dari hasil analisis dengan korelasi berganda didapatkan hubungan namun sangat lemah antara Parameter Fisika: Suhu dan Kekeruhan. Parameter Kimia : BOD, DO, Nitrat, Pospat, dan pH, dengan Kelimpahan fitoplankton dikarenakan nilai korelasi $\mathrm{r}^{2}$ - hitung 0,003 (sangat lemah) < r-tabel 0,997 yang berate Ho diterima.

Komunitas fitoplankton yang diperoleh berdasarkan indeks saprobitas adalah $(-1,625)$ dengan ini terklasifikasikan terjadinya pencemaran organik yang cukup berat/ Mesosaprobik atau termasuk tingkat pencemaran kelas 4 .

Nilai pesebaran fitoplankton dengan rata-rata 0,77 yang di peroleh dapat diartikan bahwa pesebaran fitoplankton di danau sipin memiliki pesebaran yang merata karna nilai E mendekati 1.

\section{Daftar Pustaka}

Dodi. (2016). Kajian Ekosistem Danau Sipin Kota Jambi, diakses https://dodifebri.wordpress.com/2016/11/12/kajianekosistem-danau-sipin-kota-jambi/, pada tanggal 26 September 2017 pukul 10.27, Jambi.

Effendi, H. (2003). Telaah kualitas Air Bagi Pengelolaan Sumber Daya dan Lingkungan Perairan. Kanisius. Yogyakarta.

Fardiaz, S. (1992). Pencemaran Air. Pusat Antar Universitas Pangan dan Gizi. Institut Pertanian Bogor. Kanisius. Jakarta.

Kamali. (2004), Komunitas Fitoplankton. Institut Pertanian Bogor. Bogor.

KLH. (1988). Keputusan Mentri No.02 Tahun 1988 Pasal 1 Tentang Penetapan Baku Mutu Lingkungan, Jakarta.

KLH. (2001). Peraturan Pemerintah No.82 Tentang Pengendalian Pencemaran Air, Jakarta.

Lukman, Sulastri, D.S. Said, T. Tarigan, \& T. Widiyanto. (2006). Pengelolaan Sumber daya Perairan Darat Secara terpadu di Indonesia. Bogor.

Nontji, A. (2006). Plankton, Lembaga Ilmu Pengetahuan Indonesia-Pusat Penelitian Oseanografi, Jakarta.

SLHD. (2016). Laporan Akhir Status Lingkungan Hidup Daerah Kota Jambi Tahun 2016, Jambi.
Sutrisno. (2016). Tinjauan Kuantitas dan Kualitas Air Danau Sipin Kota Jambi. Tugas Akhir S1 Universitas Batanghari, Jambi. 